\title{
Increasing of Thermal Conductivity from Mixing of Additive on a Domestic Compacted Bentonite Buffer
}

\section{국산 압축벤토나이트 완충재의 첨가제 혼합을 통한 열전도도 향상}

Jong-pyo Lee ${ }^{1,2}$, Heui-Joo Choi ${ }^{2}$, Jong-Won Choi ${ }^{2}$ and Minsoo Lee $2^{2^{*}}$

${ }^{1}$ Kyunghee University, 1732 Deokyoungdaero, Giheung-gu, Yongin, Gyeonggi-do, Korea

${ }^{2}$ Korea Atomic Energy Research Institute, 989-111 Daedeokdaero, Yuseong-Gu, Daejon, Korea

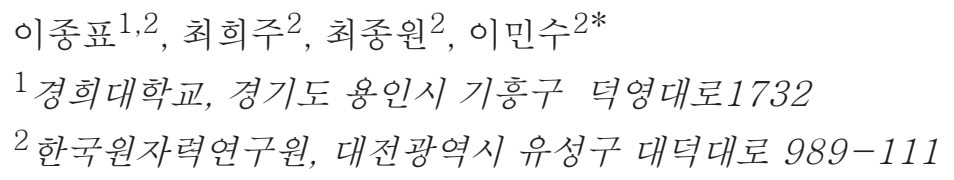

(Received August 07, 2012 / Revised November 05, 2012 / Approved December 27, 2012)

The Geyoungju Ca-bentonite with dry density of $1.6 \mathrm{~g} / \mathrm{cm}^{3}$ has been considered as a standard buffer material for the disposal of high level waste in KAERI disposal system design. But it had relatively lower thermal conductivity compared with other surrounding materials, that was one of key parameters to limit the increase of the disposal density in the disposal system. In this study, various additives were selected and mixed with the Ca-bentonite in different mixing methods in order to increase the thermal conductivity from $0.8 \mathrm{~W} / \mathrm{mK}$ to $1.0 \mathrm{~W} / \mathrm{mK}$. As an additive, CNT (Cabon Nano Tube), graphite, alumina, $\mathrm{CuO}$, and $\mathrm{Fe}_{2} \mathrm{O}_{3}$ were selected, which are chemically stable and have good thermal conductivity. As mixing methods, dry hand-mixer mixing, wet milling and dry ball mill mixing were applied for the mixing. Above all, the ball mill mixing was proved to be most effective since the produced mixture was most homogeneous and showed higher increase in the thermal conductivity. From this study, it was confirmed that the thermal conductivity for the Geyoungju Ca-bentonite could be improved by adding small amount of highly thermal conductive material to $1.0 \mathrm{~W} / \mathrm{mk}$. In conclusion, it was believed that the experimental results will be valuable in the disposal system design if the additive effects on the swelling and permeability on the compact bentonite are also approved in further studies.

Key words: HLW, Thermal conductivity, Dry density, Water contents, Additive, Mixture

현재 고준위 방사성 폐기물 심층 처분 시스템에서 기본 완충재 물질로서 건조밀도 $1.6 \mathrm{~g} / \mathrm{cm}^{3}$ 의 경주산 칼슘 벤토나이트 를 사용하고 있으나, 열전도도가 낮은 단점이 있다. 따라서 본 연구에서는 기준 완충재의 열전도율을 $0.8 \mathrm{~W} / \mathrm{mK}$ 에서 1.0 $\mathrm{W} / \mathrm{mK}$ 로 향상시키기 위한 목적으로 다양한 첨가제를 다양한 혼합 방법을 통해 배합하고 열전도도를 측정하였다. 첨가제는 $\mathrm{CNT}$ (Cabon Nano Tube), Graphite, Alumina, $\mathrm{CuO}$ 및 $\mathrm{Fe}_{2} \mathrm{O}_{3}$ 등을 사용하였다. 혼합 방법의 경우, 핸드 믹서기를 통한 건식 혼합, 습식 Milling 혼합, 건식 Ball Mill 혼합 등을 실시하였다. Ball Mill 혼합의 경우가 가장 균일하게 혼합되었기 때문에, 값 의 편차가 가장 적었고 열전도도 증가율이 가장 좋았다.

지금까지 수행된 시험에서 소량의 고열전도 물질의 첨가로 경주산 칼슘 벤토나이트의 열전도도를 $1.0 \mathrm{~W} / \mathrm{mK}$ 수준으로 용 이하게 증가시킬 수 있음을 실험적으로 확인할 수 있었다. 결론적으로, 본 연구에서 제시된 열전도 향상 방법은, 첨가제 혼합 이 벤토나이트의 기본 성질인 팽윤압과 수리전도도에 미치는 영향까지 제시된다면, 국내 고준위폐기물 처분장의 개념 설계 
에 유용하게 활용될 수 있을 것으로 기대된다.

중심단어: 고준위 방사성 폐기물, 열전도도, 건조 밀도, 함수비, 첨가제, 혼합

*Corresponding Author . E-mail: minm@kaeri.re.kr, Tel: +82.42.868.2081

\section{1. 서 론}

고준위 방사성 폐기물의 심지층 처분은 터널을 뚫고 지하 수백미터이상에서 이루어진다. 처분용기는 터널 바닥에 굴 착하여 만든 처분공에 정치시키고, 처분용기와 암반사이는 완충재 물질들로 채워진다. 이처럼 완충재는 공학적 방벽의 중요한 구성요소 중 하나이다.

완충재 물질로 주로 사용되는 물질은 벤토나이트이다. 벤 토나이트는 팽윤성을 가지는 몬모릴로나이트(montmorillonite)가 주성분이며, 나머지는 석영(quartz), 장석(feldspar), 제올라이트(zeolite), 탄산염(carbonate), 철산화물(iron oxide), 유기물(organic matter) 등으로 구성되어 있는 점토이 다. 몬모릴로나이트는 스멕타이트(Smectite)를 그룹명으로 하는 점토광물로서, 2 개의 $\mathrm{SO}_{2}$ 사면체 엽상면 사이에 알루 미늄(또는 철, 마그네슘)을 갖는 $\mathrm{Al}(\mathrm{OH})_{6}$ 팔면체 엽상면이 끼인 단위입자들이 집적된 형태로 존재한다. 엽상면은 전기 적으로 음성을 띄기 때문에 층 사이에는 $\mathrm{Na}, \mathrm{Ca}, \mathrm{Mg}$ 등의 금 속 양이온이 첨가되어 전기적으로 중성을 이루게 되며, 금 속 양이온의 종류에 따라서 $\mathrm{Na}$-벤토나이트, $\mathrm{Ca}$-벤토나이트 등으로 구분된다. 현재 한국형 처분장에서 공학적 방벽으로 사용하고자 하는 기준 벤토나이트는 압축 밀도 $1.6 \mathrm{~g} / \mathrm{cm}^{3}$ 의 경주산 천연 칼슘 벤토나이트이다. 그 구성은 몬모릴로나이 트 $70 \%$, 장석 $29 \%$, 석영 $1 \%$ 로 되어있다[1].

완충재는 처분용기를 물리적으로 보호하면서, 핵종의 이 동을 억제하는 역할을 한다. 벤토나이트는 물을 흡수하여 부피가 팽창되는 특성이 있어, 처분용기를 주위로부터 밀봉 하기에 적합한 물질이다. 하지만, 벤토나이트는 열전도율이 낮은 단점을 지니고 있다. 따라서 고준위 방사성 폐기물에 서 발생되는 붕괴열의 발산이 느려지게 되고, $100^{\circ} \mathrm{C}$ 이상으 로 증가할 경우에는 벤토나이트의 스멕타이트가 비팽윤성 의 일라이트(illite)로의 변성이 일어날 수 있다[2,3,4]. 따라 서 결국에는 완충재의 낮은 열전도는 고준위 폐기물 용기의 처분밀도를 낮추게 되어 경제적인 손실이 크게 된다.

따라서 이러한 이유로 압축 벤토나이트의 기본적인 열전도 율 향상을 위해 많은 연구가 진행되어왔다[5,6]. 일반적으로, 벤토나이트의 열전도율은 수분함량과 건조 밀도 그리고 벤 토나이트를 구성하는 광물 구성에 따라 좌우된다. 벤토나이
트는 수분함량이 높아지면 열전도율이 증가한다. 하지만, 낮 은 수리전도도를 지니고 있기 때문에, 완전히 포화되는데 오 랜 시간이 걸린다. 따라서 심지층 처분 초기에 발생되는 붕괴 열은 불포화된 압축 벤토나이트 완충재의 열적 특성에 의해 발산시켜야 한다[7]. 그리고 벤토나이트를 압축정도를 나타 내는 건조 밀도가 증가될수록 열전도율 또한 상승된다.

따라서 벤토나이트 완충재의 열전도를 향상시키기 위해 열전도가 높은 무기 첨가제를 소량 첨가하는 연구가 여러 나 라에서 진행되었다. 첨가제로서는 열전도가 높은 석영이 다 량 함유되어있는 모래, 혹은 열전도가 높은 흑연을 사용하여 완충재의 열전도율 향상시키는 연구가 진행되었다 $[7,8,9]$.

이에 본 연구에서는 KAERI에서 기준 완충재로 지정된 건 조밀도 $1.6 \mathrm{~g} / \mathrm{cm}^{3}$ 의 경주산 천연 칼슘 벤토나이트에 대해 열 전도도 향상을 목적으로 수행하게 되었다. 지정된 경주산 천 연 칼슘 벤토나이트 완충재는 열전도도가 $0.8 \mathrm{~W} / \mathrm{mK}$ 로 보고 되고 있으며[1], 본 연구에서는 열전도도를 $20 \%$ 향상시킨, 즉 열전도도가 $1.0 \mathrm{~W} / \mathrm{mK}$ 를 얻을 수 있는 효과적인 첨가제 와 요구 함량을 얻고자 하였다. 열전도도 $1.0 \mathrm{~W} / \mathrm{mk}$ 는 동일 한 조건의 일본 완충재(건조밀도 $1.6 \mathrm{~g} / \mathrm{cm}^{3}$, 함습율 $10 \mathrm{wt} \%$, Na-bentonite)의 값을 목표로 하고 있다[10].

연구에서는 먼저 건조밀도와 함수비에 따른 경주산 천연 칼슘 벤토나이트의 열전도율의 변화를 측정하여 첨가제가 포함되지 않은 완충재의 순수한 열전도도 특성을 구하고자 하였다. 그리고 얻어진 표준값과 동일한 건조밀도 및 수분 함량에서, 첨가제가 혼합된 압축 벤토나이트의 열전도율을 비교해 보고자 하였다. 열전도 향상을 위한 첨가제로는 열 전도율이 높으면서도 장기간 화학적 변성이 없는 다양한 무 기물을 선택하였다.

\section{2. 본 론}

\section{1 장비 개발 개념}

\subsection{1 벤토나이트}

본 연구에 사용된 벤토나이트는 경북 경주시 양남면 소재 제29호 진명광산에서 재취한 것이다. 벤토나이트의 화학조 성은 Table 1과 같다[11]. 채취한 벤토나이트 시료는 $105^{\circ} \mathrm{C}$ 
에서 24시간 동안 건조시킨 후, 200 메쉬(mesh) 체를 90\% 이상 통과하도록 분쇄한 분말이다[1].

실험을 시작하기 전에 벤토나이트 함수비를 측정하기 위 하여 벤토나이트 파우더의 열전도도를 측정해보았다. 항온 건조 오븐에서 $120^{\circ} \mathrm{C}$ 조건으로 24 시간동안 건조시켜서, 무 게 감소량을 토대로 측정해본 결과 $13.2 \mathrm{wt} \%$ 로 나왔다.

압축 벤토나이트 블록 제작을 위해 Fig. 1과 같이 몰드를 제 작하였다. 몰드는 가로 $50 \mathrm{~mm}$, 세로 $100 \mathrm{~mm}$, 높이 $10 \mathrm{~mm}$ 로 환산된 수분을 포함한 겉보기 밀도는 약 $1.81 \mathrm{~g} / \mathrm{cm}^{3}$ 정도이 고, 블록 자체의 벤토나이트 건조밀도는 $1.6 \mathrm{~g} / \mathrm{cm}^{3}$ 정도이 었다. 압축 블록은 몰드에 벤토나이트를 넣은 후, 유압 프레 스를 이용하여 제작하였다.

\subsection{2 첨가제}

Table 2에 벤토나이트 완충재의 열전도율을 향상시키기 위해 사용된 첨가제의 일반적인 열전도도를 나타내었으며, 첨가제들은 상업적으로 시판하는 것을 구입하였다. 선택된 첨가제들은 열전도율이 높으면서 화학적으로 안정한 것들 이다. CNT의 경우에는 선형 구조를 가지고 있어 축방향으 로는 매우 높은 열전도율을 지니고 있기 때문에 복합재료의 열전도율 향상에 많이 이용되고 있다. Graphite는 이미 벤 토나이트 열전도 향상에 효과가 있다고 알려져 있으며[8,9], $\mathrm{CuO}$ 와 $\mathrm{Fe}_{2} \mathrm{O}_{3}$, Alumina의 경우에는 화학적으로 매우 안정 한 산화물이면서 비교적 높은 열전도율을 지니고 있어 선 정하였다.

\section{2 실험}

\subsection{1 건조 밀도와 함수비 조절}

벤토나이트의 건조 밀도와 함수비에 의한 영향을 알아보 기 위해 건조 밀도와 함수비를 달리하는 시험을 수행하였 다. 압축 블록의 몰드 크기가 일정하기 때문에, 실험에서

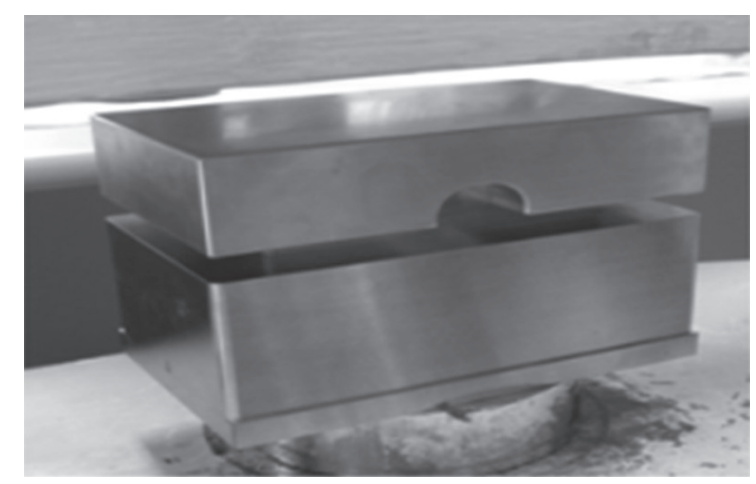

Fig. 1. Compression mold for the compaction of bentonite powder.
는 가압력은 일정하게 하고, 시료의 양을 조절하면서 다양 한 건조밀도의 블록을 제작하였다. 그리고 제작된 압축블록 은 $120^{\circ} \mathrm{C}$ 로 유지된 건조 오븐에서 24 시간 완전 건조시킨 후, Fig. 2와 같이 습도가 높은 수조 위에 일정기간 노출시켜, 함 습에 의한 무게 증가량으로 함수비를 조절하였다.

\subsection{2 첨가제 혼합 방법}

벤토나이트와 첨가제의 혼합이 균일하게 되었을 경우에 열전도율 향상 효율이 높아질 것으로 기대하였다. 따라서 다양한 벤토나이트와 첨가제의 혼합 방법을 실시하였고, 열 전도율 향상 효율을 비교해보았다. 특히, CNT와 같이 벤토 나이트와 밀도 차이가 큰 경우에는 일반적인 혼합 방법으로 는 혼합이 잘 이루어지지 않았다. 그러므로 CNT의 경우에 는 보다 다양한 혼합 방법을 수행하였고, 이외에 4 가지 물질 에 대해서는 Mixer Stirring 혼합과 Roller Stirring 혼합을 실 시하였다.

건조 분말 상태의 CNT와 벤토나이트를 Mixer Stirring 혼합 하였을 경우, 밀도가 낮은 CNT가 벤토나이트 분말과 균일하 게 혼합되지 않았고 벤토나이트와도 쉽게 분리되었다. 그래 서 CNT를 물과 알콜, Ethyl Ether(저비점 유기 용제)에 첨가 하여 분산시킨 후에 혼합시켰지만, 분산 자체가 잘 이루어지 지 않았다. 따라서 Homogenizer(IKA, ULTRA-TURRAX $($ ) 를

Table 1. Chemical composition of Gyeongju Ca-Bentonite

\begin{tabular}{cc}
\hline Oxides & wt $\%$ \\
\hline $\mathrm{SiO}_{2}$ & 56.8 \\
\hline $\mathrm{Al}_{2} \mathrm{O}_{3}$ & 19.96 \\
\hline $\mathrm{Fe}_{2} \mathrm{O}_{3}$ & 6.03 \\
\hline $\mathrm{FeO}$ & 0.15 \\
\hline $\mathrm{CaO}$ & 2.59 \\
\hline $\mathrm{MgO}$ & 0.77 \\
\hline $\mathrm{K}_{2} \mathrm{O}$ & 0.93 \\
\hline $\mathrm{Na}_{2} \mathrm{O}$ & 2.95 \\
\hline $\mathrm{MnO} \mathrm{TiO}_{2}$ & 0.04 \\
\hline $\mathrm{P}_{2} \mathrm{O}_{5}$ & 0.83 \\
\hline
\end{tabular}

Table 2. Additive materials for the improvement of thermal conductivity of Ca-bentonite

\begin{tabular}{cccc}
\hline Additives & $\begin{array}{c}\text { Thermal Conductivity } \\
(\mathrm{W} / \mathrm{mK})\end{array}$ & Company & Purity $(\%)$ \\
\hline $\begin{array}{c}\mathrm{CNT} \\
(\mathrm{WMNT})\end{array}$ & $\begin{array}{c}3500(\text { axis, } \mathrm{SWNT}) \\
1.52(\text { side, } \mathrm{SWN})\end{array}$ & - & 99 \\
\hline Graphite & $120 \sim 140$ & KOMEX & 99.0 \\
\hline Alumina & 30 & SHOWA & 99.5 \\
\hline $\mathrm{Fe}_{2} \mathrm{O}_{3}$ & 7.74 & SHOWA & 98.0 \\
\hline $\mathrm{CuO}$ & 37.6 & SHOWA & 98.5 \\
\hline
\end{tabular}



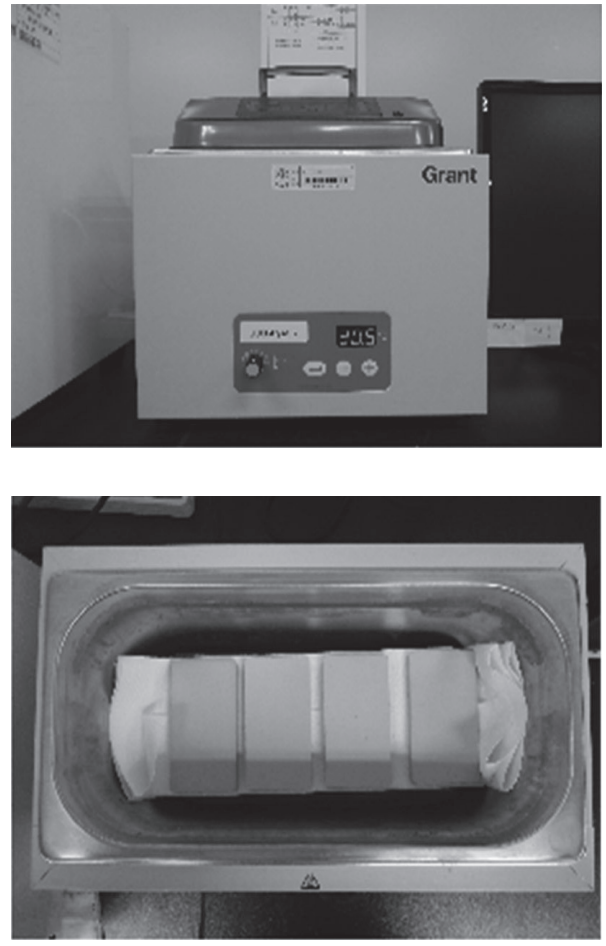

Fig. 2. Water content control of compact bentonite blocks in a water bath.

이용하여 CNT를 용매에 분산시킨 후, 용매과 벤토나이트를 섞는 시도를 수행하였다. 용매로는 물과 Ethyle Ether을 사 용하였다. 하지만, Homogenizer를 통한 CNT의 분산은 일 시적으로 분산된 것처럼 보였지만, 시간이 지나면 CNT끼리 뭉치면서 CNT 입자들의 엉김이 발생하였다. Fig. 3에 CNT 분말의 Homogenizer에 의한 분산상태를 나타내었다.

또 다른 방법으로, CNT 입자들을 물리적으로 갈아서 벤토 나이트와 혼합시키는 실험을 실시하였다. 우선, 벤토나이트 와 $\mathrm{CNT}$ 의 혼합물에 물을 첨가하여 맷돌 방식의 Mill Mixer기 로 10 회에 걸쳐 반복하여 혼합하였다. 얻어진 혼합물을 Fig. 4 에 나타내었다. 이 혼합물을 오븐에 넣고 건조시킨 후, 함 수비가 $12.4 \mathrm{wt} \%$ 되도록 물을 첨가하고 비닐 팩에 밀봉하여 하룻 동안 숙성하였다. 숙성된 혼합물을 압축하여 압축 블록 을 얻었다(Fig. 5(a)). Mill Mixer기로 혼합된 압축블록의 경 우, 육안으로 혼합물이 균질한 상태에 있지 못하다고 판단되 었다. 그래서 다시 혼합물을 건조상태에서 grinder로 갈아서 분말화 한 후 Fig. 5(b)와 같이 블록으로 제작하였다.

또한, 혼합용 Mixer 사용으로 인한 벤토나이트 자체의 열전도도에 대한 영향 여부를 판단하기 위하여, 똑같은 공 정으로 첨가제를 넣지 않고 벤토나이트 블록을 제작하였다 (Fig. 6).

한편, Mill Mixer를 이용한 혼합방법은 재료의 손실률이 매우 컸고, 이는 첨가제 함량에 영향을 미칠 것으로 판단되 (a)

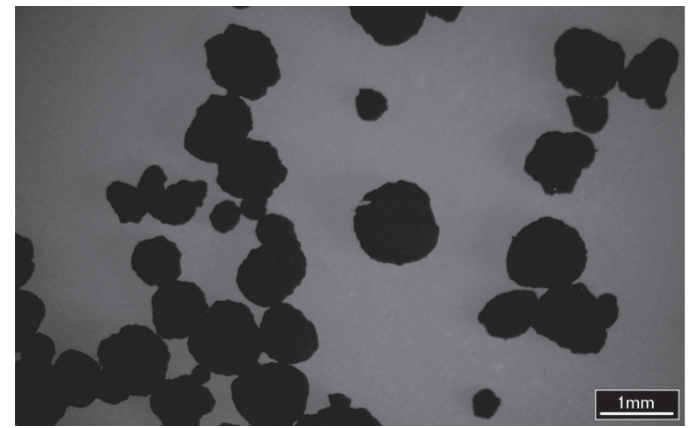

(b)

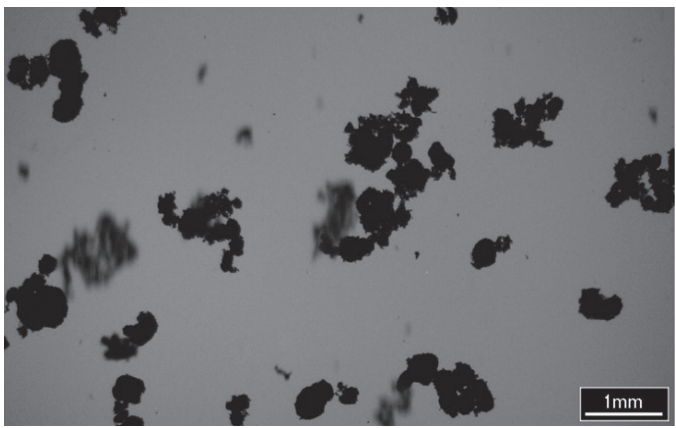

(c)

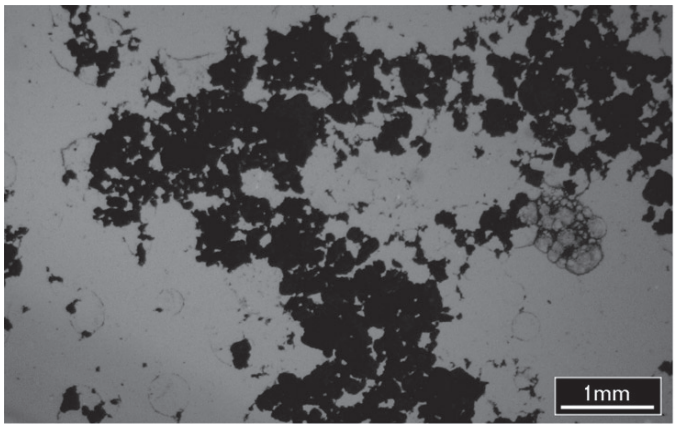

Fig. 3. View of dispersed CNT powders by a homogenizer; (a) untreated CNT powders (b) CNT powders dispersed in water (c) CNT powders dispersed in ethyl ether.

었다. 그래서 건조 상태의 CNT를 갈아서 벤토나이트와 혼 합을 실시하였다. 처음에는 Mixer Stirring 혼합된 벤토나이 트와 CNT를 막대사발에 넣은 후 함께 갈았고, 이렇게 얻어 진 압축 벤토나이트 블록을 Fig. 7에 나타내었다. 그 다음에 는 CNT만을 막대사발에 넣어서 갈은 후에, 벤토나이트와 의 Stirring Mixing을 하였고, 얻어진 벤토나이트 압축블록을 Fig. 8에 나타내었다.

지금까지 언급된 혼합 방법들은 매번 똑같은 상태의 압 축 블록을 얻는 재현성이 부족하였다. 그래서 Ball Mill를 이 용한 혼합을 실시하였다. Ball Mill Mixing의 장점은 CNT 와 벤토나이트를 건조 상태에서 혼합시킬 수 있으면서, 손 실률도 적고, 공정도 간단하면서, 균일한 RPM과 혼합시간 으로 공정의 일관성을 높일 수 있다는데 있다. 하지만 Jar 내부의 벽면에 혼합물들이 들러붙어 균일한 혼합을 방해하 는 경향이 있었다. 이러한 단점을 보완하기 위하여, Fig. 9 와 같이 PET 봉지에 혼합물을 넣은 후에 Ball Mill Mixing 

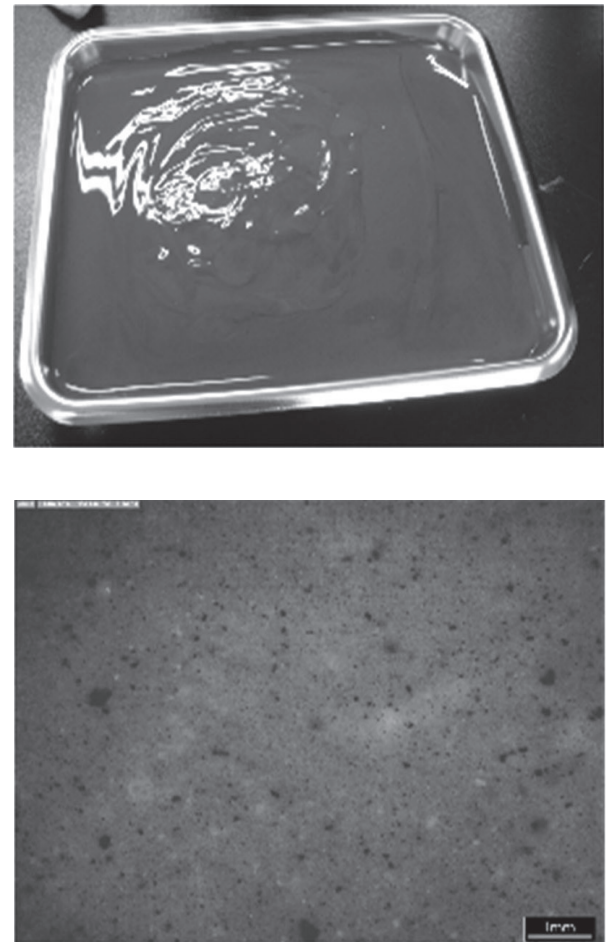

Fig. 4. Aqueous mixture of bentonite and $1.14 w t \%$ CNT producted by a Mill Mixing method.

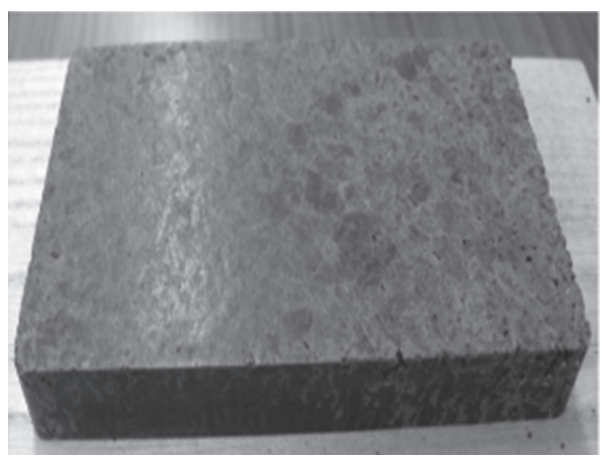

(a)

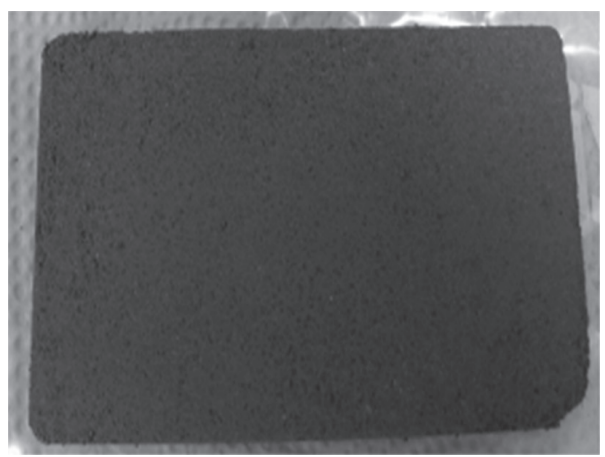

(b)

Fig. 5. Mill Mixed bentonite and CNT block (a), and Dry grinded bentonite and CNT Block.

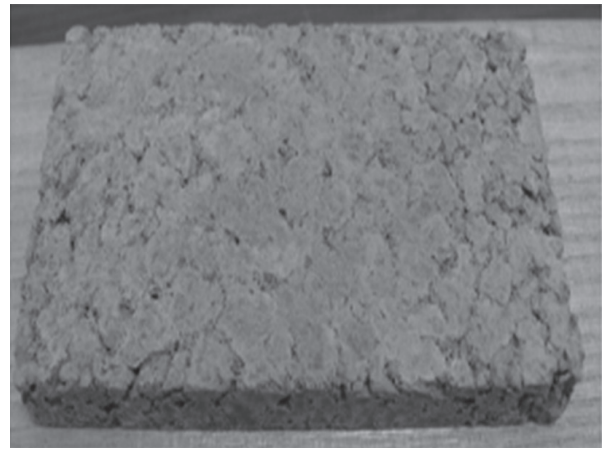

(a)

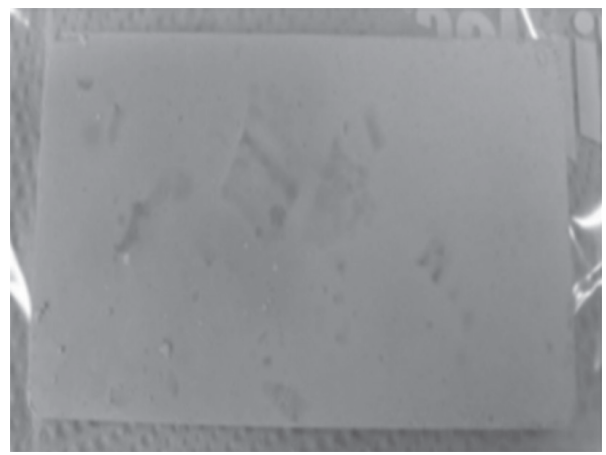

(b)

Fig. 6. Mill treated bentonite block (a), and Dry grinded bentonite Block.
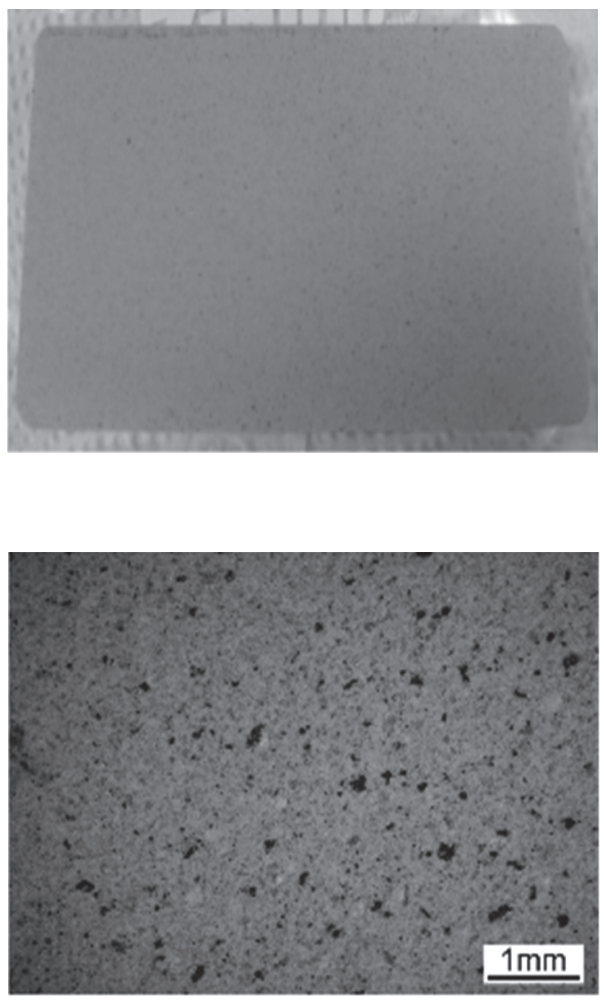

Fig. 7. CNT and bentonite mixed block by hand mixing in a bowl. 

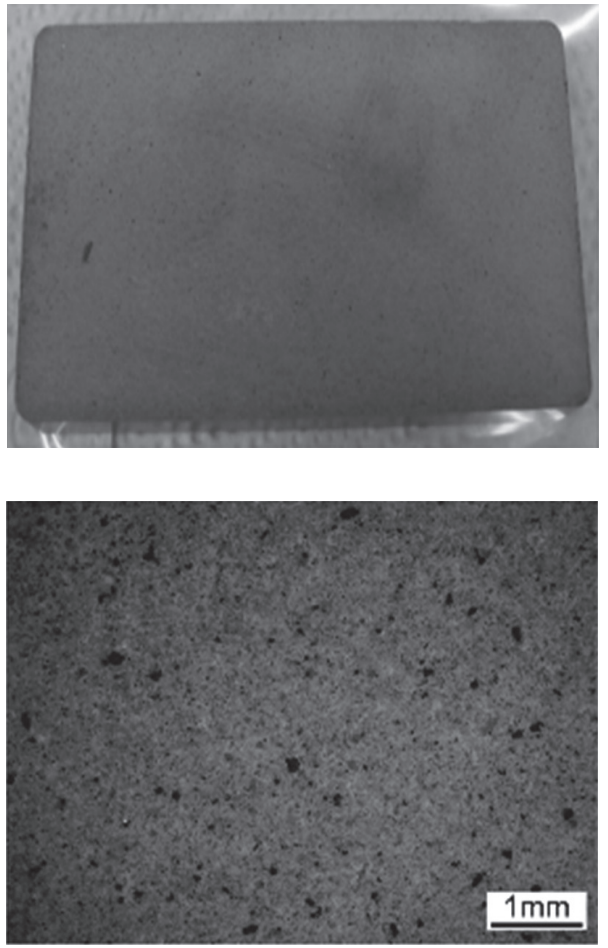

Fig. 8. Bentonite and grinded CNT mixed block.

을 실행하였다. 혼합 조건은 $100 \mathrm{RPM}$ 으로 2 시간동안 멈추 지 않고 실시하였다.

Graphite와 같이 벤토나이트와 밀도차가 없어서 혼합이 잘되는 경우에도 볼이 없는 상태에서 Roller Stirring 혼합 을 실시하였다.

\section{3 열전도율 측정 방법}

\subsubsection{QTM-500 (Quick Thermal Conductivity Meter)}

본 연구에서 블록의 열전도율를 측정하기 위해 비정상 열 선법을 이용한 측정기구인 QTM-500 (Kyoto Electronics)을 사용하였다. 비정상 열선법은 매질 내의 열선에 일정한 열 량을 공급 시 시간과 열선의 온도 상승의 관계를 이용한 것 이다.

비정상 열선법의 공식은 기본적으로 열확산 방정식을 이 용한다. 여기서의 열확산 방정식은 이상적인 조건 $\left(\mathrm{r}^{2} / 4 \alpha \mathrm{t}\right.$ 《< 1)으로 가정된다.

$$
\begin{aligned}
& T(r, t)-T_{0}=\frac{q}{4 \pi \lambda} \ln \left(\frac{4 \alpha t}{r^{2} C}\right) \Leftrightarrow T(r, t)-T_{0} \\
& =\frac{q}{4 \pi \lambda}\left[\ln \left(\frac{4 \alpha}{r^{2} C}\right)+\ln (t)\right]
\end{aligned}
$$

위의 열확산 방정식을 미분하게 되면, 다음과 같이 열전도율 값을 얻을 수 있는 식이 된다.

$$
\frac{d T(r, t)}{d \ln (t)}=\frac{q}{4 \pi \lambda} \Leftrightarrow \lambda=\frac{q\left(\ln t_{2} / t_{1}\right)}{4 \pi\left(T_{2}-T_{2}\right)}
$$

where, $\lambda$ is the thermal conductivity $(\mathrm{W} / \mathrm{mK}), \alpha$ is a thermal diffusivity $\left(\mathrm{m}^{2} / \mathrm{s}\right)$

$r$ is the radial distance from the center of wire after heated,

$t$ is heating time, $\mathrm{q}$ is the heating power per unit length of the wire,

$\alpha=\mathrm{k} / \rho_{\mathrm{C}_{\mathrm{p}}}, \rho$ is the density $\left(\mathrm{kg} / \mathrm{m}^{3}\right)$,

$\mathrm{c}_{\mathrm{p}}$ is the heat capacity of the test material $(\mathrm{J} / \mathrm{kgK})$,

$\mathrm{C}=\exp (\gamma)=1.78, \gamma=0.5772157$ is the Euler's constant $[12,13]$.

열전도율 측정 전극으로는 QTM-500 PD-11을 사용하였 다. 이 전극은 열선의 위쪽은 열선에 발생된 열이 블록으 로만 확산시키기 위하여 단열재인 유리섬유로 제작되어 있 다. 또한, 전극 형태상 블록의 표면에서의 열전도율을 구하 기 때문에, 블록 표면 근처의 조성 및 구조에 많은 영향을 받는다.
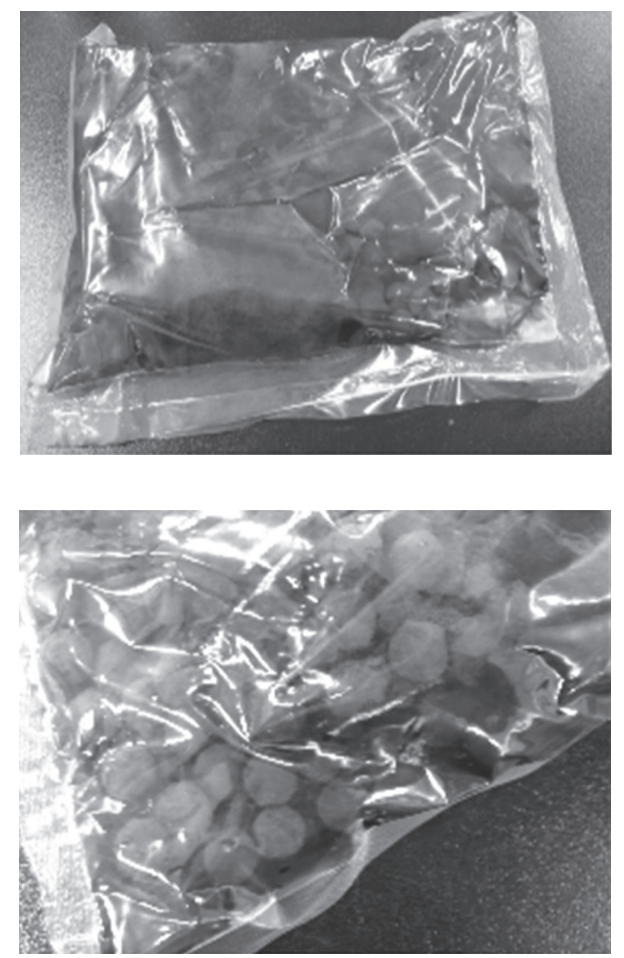

Fig. 9. Figures of Ball Mill mixing using a PET pack. 


\section{3. 결과 및 논의}

\section{1 국산 칼슴 벤토나이트의 열전도율}

첨가제 함량에 따른 국산 칼슘 벤토나이트의 열전도율 변 화를 알아보기 위하여, 건조밀도와 함수비에 따른 국산 칼슘 벤토나이트의 열전도율을 측정하였다.

Fig. 10은 수분함량을 달리했을 경우, 건조밀도에 따른 국 산 칼슘벤토나이트의 열전도율 변화를 나타낸다. 우선 국산 칼슘-벤토나이트는 건조밀도가 증가할수록 열전도율이 증 가하는 것을 볼 수 있다. 건조밀도가 높을수록 고형물의 접 촉면이 넓어지고, 열전도를 저해하는 공기 함유량이 줄어들 기 때문에 열전도율이 높아지는 것으로 판단된다. 또한, 수 분함량이 증가할수록 열전도율이 높아졌으며, 이는 입자 사 이의 기공을 물이 채워짐에 따라서 열전도율이 높아지는 것 으로 판단된다. 하지만, 함습율에 따른 그래프 기울기의 변 화는 뚜렷하지 않다. Fig. 11은 함수비에 따른 국산 칼슘 벤 토나이트의 열전도도 변화를 나타낸 것이다. 우선 국산 칼 슘-벤토나이트는 수분함량이 증가할수록 열전도도가 증가 하는 것을 볼 수 있다. 이처럼 건조밀도와 수분함량에 서로 에게 영향을 미치는 이유는 수분함량과 건조밀도가 비례적

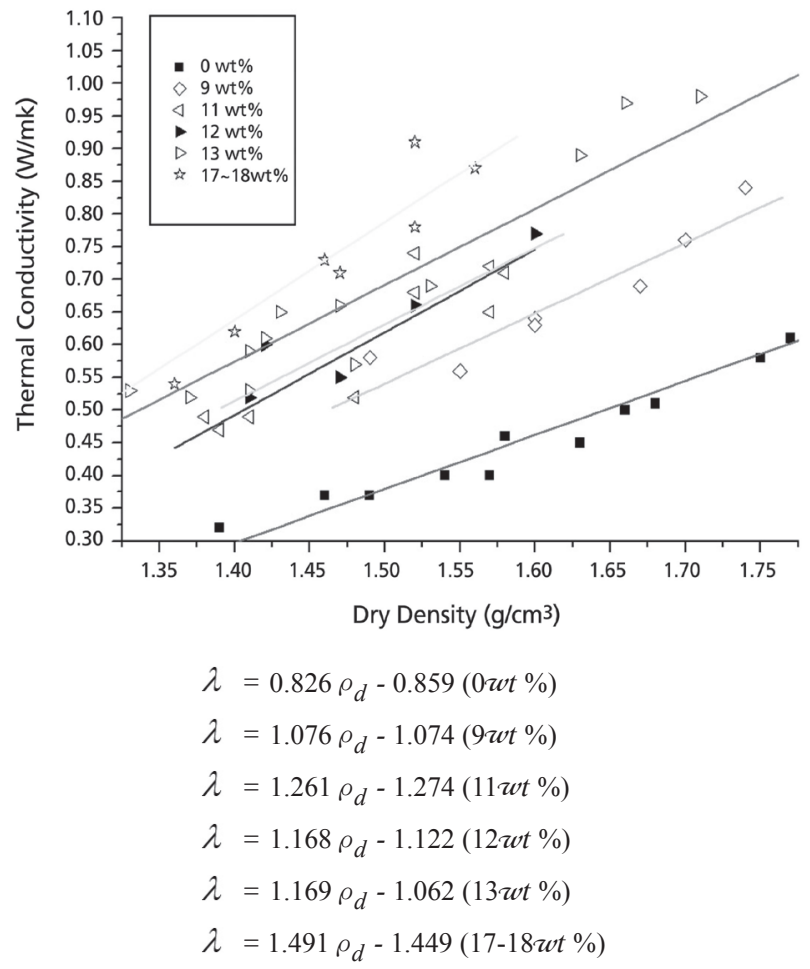

Fig. 10. Effect of dry density on the thermal conductivity of Ca-Bentonite with different water content.
인 관계 때문이라 판단된다.

\section{$3.2 \mathrm{CNT}$ 와 칼슘 벤토나이트 혼합}

Table 3는 경주 칼슘 벤토나이트와 CNT의 다양한 혼합 방 법에 따른 열전도율 변화와 CNT 첨가량에 따른 열전도율 변 화를 나타낸다. 기본적으로 CNT $1 \mathrm{wt} \%$ Mixer Stirring 혼합 하였을 때, 약 $0.05 \mathrm{~W} / \mathrm{mK}$ 정도 증가하는 것으로 나타났지 만, 이 경우에 외관상으로 관찰될 정도로 $\mathrm{CNT}$ 가 불균일하 게 혼합되었다. CNT $1.14 \mathrm{wt} \%$ 를 Mixer Milling 습식 혼합하 였을 때는 약 $0.31 \mathrm{~W} / \mathrm{mK}$ 증가하는 것으로 나타났고, 알맹 이를 분말 형태로 만들었을 때는 약 $0.22 \mathrm{~W} / \mathrm{mK}$ 증가하였 다. 따라서 혼합물이 알맹이 형태일 때 보다 열전도율이 높 게 측정된다는 것을 알 수 있다. 이는 알맹이가 큰 경우에는 압축 블록의 밀도가 불균일하기 때문으로 판단된다. Mixer 를 통한 습식 혼합의 경우에 열전도율 향상은 좋았으나, 실 험 과정에서의 손실률이 매우 크기 때문에 CNT가 함량에 불 분명해진다고 판단된다. 건식 상태에서 Milling 혼합 방법들 의 경우에는 열전도율 향상 효율에는 큰 차이는 없었지만, Ball Mill 혼합의 경우에 다른 방법들보다 비교적 균일한 공 정으로 혼합되므로, 결과값의 편차가 작게 나왔다.

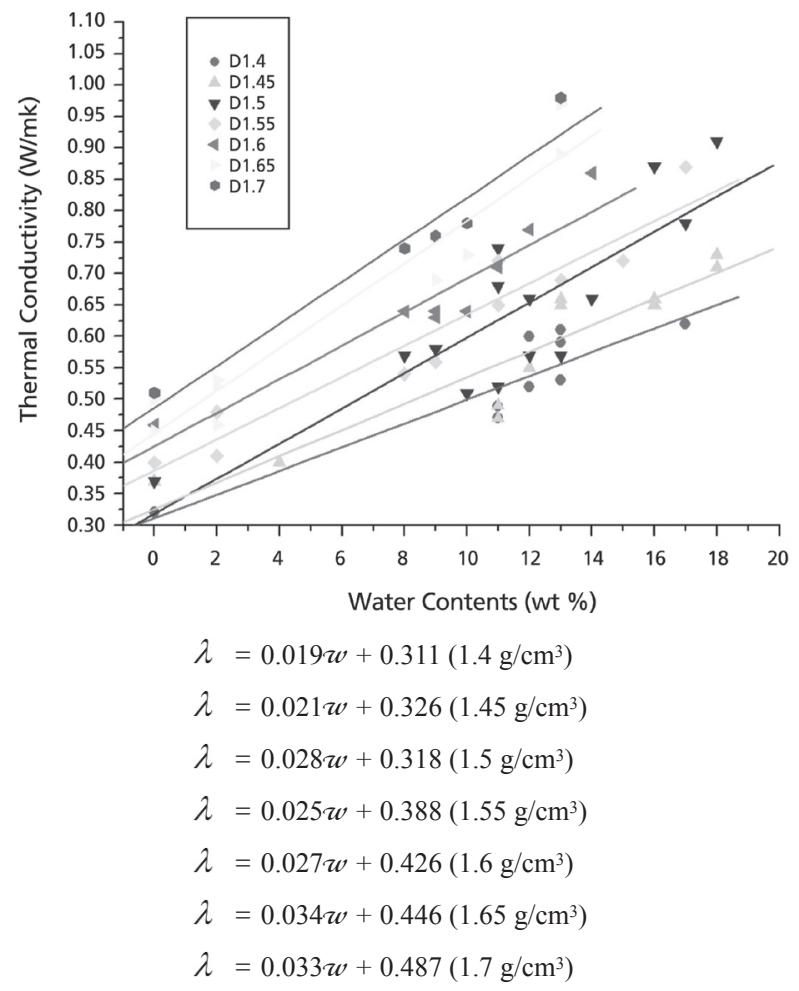

Fig. 11. Effect of water content on the thermal conductivity of Ca-Bentonite with different dry density. 
Fig. 12은 Ball Mill 혼합과 Mill and Stirring 혼합에 대하 여 첨가제량에 따른 열전도율 변화를 나타낸다. Ball Mill 혼 합의 경우, 첨가제 함량과 비례하여 열전도율이 상승된 것으 로 보았다. $1 \mathrm{wt} \%$ 함량당 약 $0.044 \mathrm{~W} / \mathrm{mK}$ 증가되었고, 이는 건조밀도 $1.6 \mathrm{~g} / \mathrm{cm}^{3}$ 벤토나이트를 기준으로 $5.5 \%$ 정도 열전 도율이 상승된 것이다. 반면에 Mixer Stirring 혼합의 경우에 는 열전도율 증가가 첨가제량에 비례하지 않았다. 이는 첨 가제와 벤토나이트가 균질하게 혼합이 되지 않았기 때문이 라고 보았다.

본 연구에서는 열전도율이 매우 높은 CNT를 혼합하였지만, 열전도율 상승은 높지 않게 나타났다. 그 원인으로 CNT가 횡 축으로는 수천 $\mathrm{W} / \mathrm{mK}$ 정도의 높은 열전도율은 지니지만, 종

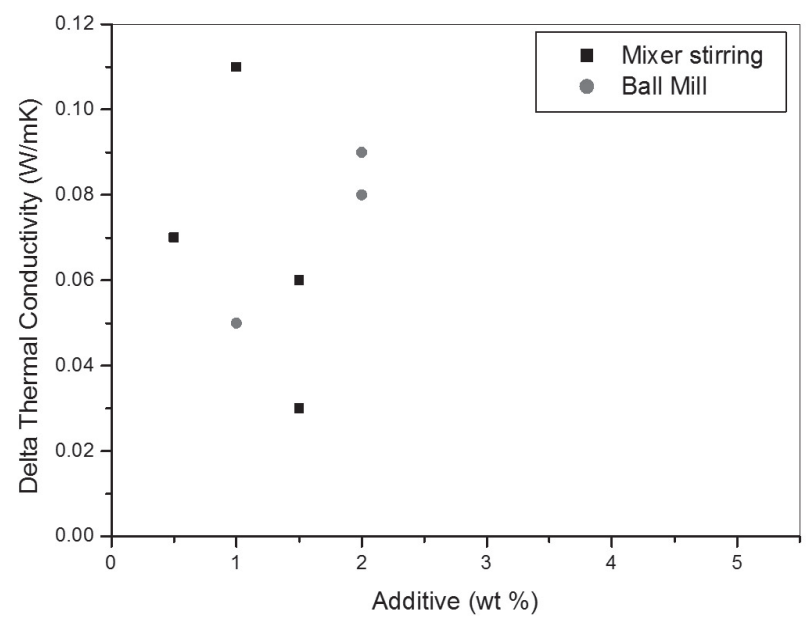

Fig. 12. Thermal conductivity of Ca bentonite with different CNT Contents.
축으로는 그에 비해 매우 낮은 $1 \sim 2 \mathrm{~W} / \mathrm{mK}$ 의 열전도율을 지니 기 때문이라 판단된다. 또한, 문헌에 따르면 MWNT(Multi-wall carbon nanotube)는 고립되어진 한 가닥일 경우 매우 높은 열 전도율을 지니지만, 여러 가닥이 뭉쳐서 엉켜있을 경우에는 벤 토나이트와 나노튜브 계면과 나노튜브-나노튜브 계면에서의 높은 열저항 때문에 예상보다 낮은 열전도율 증가가 일어난 다고 한다[14].

\subsection{Graphite와 칼슘 벤토나이트의 혼합}

Table 4는 경주산 칼슘 벤토나이트와 Graphite의 혼합 방 법에 따른 열전도율 변화와 Graphite 첨가량에 따른 열전 도율 변화를 나타내었다. Graphite의 경우에는 CNT와 달 리 벤토나이트와의 밀도차가 적기 때문에 벤토나이트와 혼 합이 잘 이루어지기 때문에, Mixer stirring 혼합과 Roller stirring 혼합을 실시하였다.

Fig. 13은 Graphite의 첨가량에 따른 열전도율 변화를 나 타낸다. Graphite가 $1 \mathrm{wt} \%$ 첨가된 경우를 살펴보았을 때, 두 가지 혼합 방법에 대하여 열전도율이 약 $0.09 \mathrm{~W} / \mathrm{mK}$ 증가 하는 것으로 나타났다. 그리고 두 가지 혼합 방법 모두 첨가 제량이 증가할수록 열전도율이 비례적으로 증가하였다. 그 러나 열전도도 증가율의 경우에는 $1 \mathrm{w} t \%$ 당 Roller stirring 혼 합 블록은 $0.095 \mathrm{~W} / \mathrm{mK}$ 정도이고, Mixer stirring 혼합 블록 은 $0.06 \mathrm{~W} / \mathrm{mK}$ 정도로 나타났다. 건조밀도 $1.6 \mathrm{~g} / \mathrm{cm}^{3}$ 벤토 나이트를 기준으로 보면, 각각 $12.3 \%, 7.8 \%$ 정도 상승된 것 이다. 이처럼 Roller stirring 혼합의 경우에 열전도율 높게

Table 3. Thermal conductivity of Ca-Bentonite with different mixing method

\begin{tabular}{|c|c|c|c|c|c|c|c|}
\hline \multirow{2}{*}{\multicolumn{2}{|c|}{ Mixing Method }} & \multirow{2}{*}{$\begin{array}{c}\text { Additive Contents } \\
\text { (wt } \%)\end{array}$} & \multirow{2}{*}{$\begin{array}{c}\text { Dry } \\
\text { Density } \\
\left(\mathrm{g} / \mathrm{cm}^{3}\right)\end{array}$} & \multirow{2}{*}{$\begin{array}{l}\text { Water } \\
\text { Content } \\
(\mathrm{wt} \%)\end{array}$} & \multicolumn{3}{|c|}{ Thermal Conductivity (W/mK) } \\
\hline & & & & & Mixture & Pure & Gap \\
\hline \multicolumn{2}{|c|}{ Mixer Stirring Mixing } & 1.000 & 1.580 & 13.03 & 0.8400 & 0.79 & 0.05 \\
\hline \multirow{2}{*}{$\begin{array}{l}\text { Mixer Mill } \\
\text { Mixing }\end{array}$} & - & 1.140 & 1.690 & 14.16 & 1.260 & 0.95 & 0.31 \\
\hline & $\begin{array}{c}\text { Adding } \\
\text { Mill Mixing }\end{array}$ & 1.140 & 1.490 & 13.96 & 0.93 & 0.71 & 0.22 \\
\hline \multirow{5}{*}{$\begin{array}{c}\text { Mill Mixing } \\
\text { in Bowl }\end{array}$} & Stirring \& Mill & 1.000 & 1.490 & 12.73 & 0.72 & 0.68 & 0.04 \\
\hline & \multirow{4}{*}{ Mill \& Stirring } & 0.5000 & 1.520 & 13.11 & 0.78 & 0.71 & 0.07 \\
\hline & & 1.000 & 1.650 & 13.23 & 0.98 & 0.87 & 0.11 \\
\hline & & \multirow{2}{*}{1.500} & 1.500 & 13.01 & 0.75 & 0.69 & 0.06 \\
\hline & & & 1.480 & 12.56 & 0.7 & 0.67 & 0.03 \\
\hline \multirow{4}{*}{\multicolumn{2}{|c|}{ Ball Mill Mixing }} & \multirow{2}{*}{1.000} & 1.600 & 12.87 & 0.86 & 0.81 & 0.05 \\
\hline & & & 1.610 & 12.66 & 0.87 & 0.82 & 0.05 \\
\hline & & \multirow{2}{*}{2.000} & 1.560 & 12.90 & 0.85 & 0.76 & 0.09 \\
\hline & & & 1.560 & 12.76 & 0.84 & 0.76 & 0.08 \\
\hline
\end{tabular}


증가하는 것은 Graphite $1 \mathrm{wt} \%$ 일 때는 첨가제 함량이 매우 적어 혼합 정도에 차이가 없지만, 첨가제 함량이 증가할수 록 Roller stirring 혼합이 더 균일하게 혼합되었기 때문이라 고 판단된다.

\subsection{Alumina, $\mathrm{CuO}$ 및 $\mathrm{Fe}_{2} \mathrm{O}_{3}$ 와 칼슴 벤토 나이트의 혼합}

Table 5는 경주 칼슘 벤토나이트와 Alumina, $\mathrm{CuO}$ 및 $\mathrm{Fe}_{2} \mathrm{O}_{3}$ 첨가에 따른 열전도율 변화를 나타낸 것이다. Alumina, $\mathrm{CuO}$ 및 $\mathrm{Fe}_{2} \mathrm{O}_{3}$ 세 산화물은 벤토나이트와 혼합이 잘 되었기 때문 에 단순하게 Mixer stirring 혼합만을 실시하였다.

Fig. 14은 Table 5의 결과값을 그래프로 나타낸 것이다. Fig. 14 을 보면, Alumina의 경우에는 첨가제량 $1 \mathrm{wt} \%$ 증가할 때 마다 열전도율이 약 $0.023 \mathrm{~W} / \mathrm{mK}$ 증가하는 것으로 나타

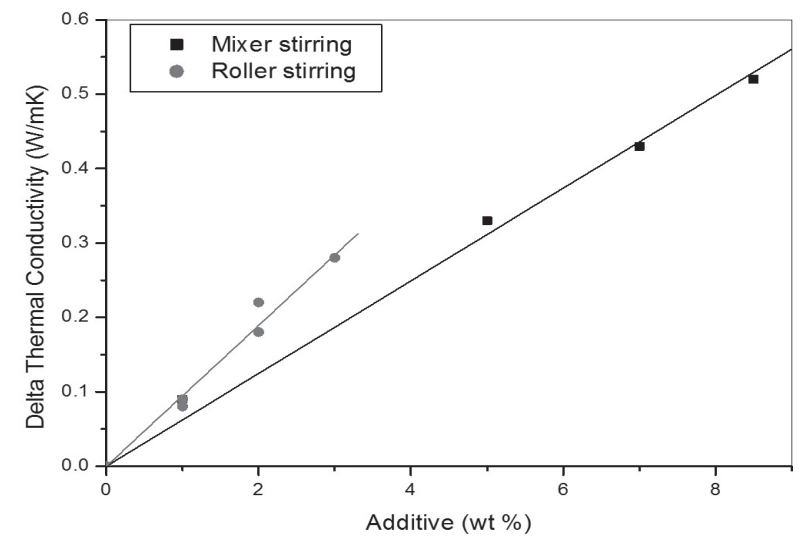

Fig. 13. Thermal conductivity of Ca bentonite with different graphite Contents.
났고, 비교적 비례하게 증가하였다. 하지만, $\mathrm{CuO}$ 나 $\mathrm{Fe}_{2} \mathrm{O}_{3}$ 의 경우에는 뚜렷하게 함량에 따라 비례하여 증가하는 결과를 얻지는 못하였다. 결론적으로 세 가지 물질 중에는 Alumina 가 열전도율을 효과적으로 증가시키는 것으로 보였다.

\section{4. 결 론}

현재 한국형 처분장에서 공학적 방벽으로 사용하고자 하 는 기준 벤토나이트는 압축 밀도 $1.6 \mathrm{~g} / \mathrm{cm}^{3}$ 의 경주산 천연 칼슘 벤토나이트이다. 따라서 본 연구에서는 건조 밀도 1.6 $\mathrm{g} / \mathrm{cm}^{3}$ 경주산 천연 칼슘 벤토나이트의 열전도율을 $20 \%$ 향 상시켜서, 일본에서 사용하고 있는 나트륨 벤토나이트의 열 전도율과 비슷한 $1.0 \mathrm{~W} / \mathrm{mK}$ 를 만들기 위한 목적으로 다양 한 첨가제를 혼합하였다. 또한, 열전도율을 보다 효율적으 로 증가시키기 위해 다양한 혼합 방법도 실시하였다. 우선,

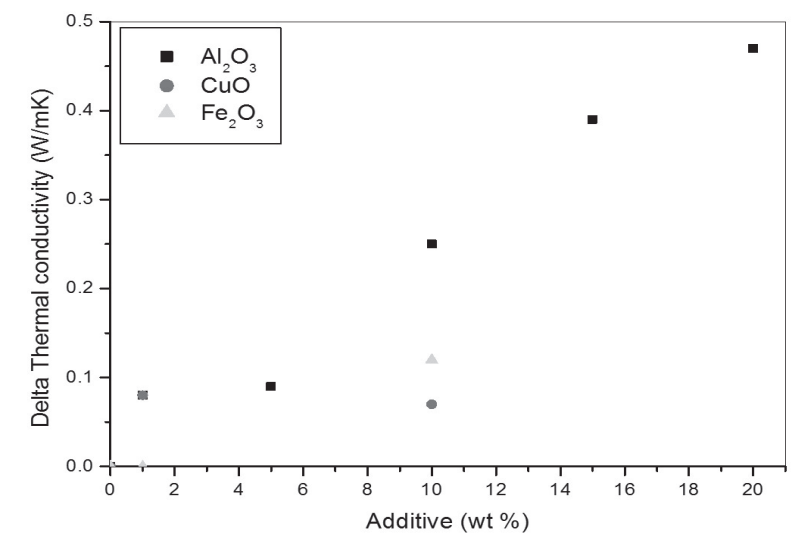

Fig. 14. Thermal conductivity of $\mathrm{Ca}$ bentonite with different Alumina, $\mathrm{CuO}$, and $\mathrm{Fe}_{2} \mathrm{O}_{3}$ Contents respectively.

Table 4. Thermal conductivity of the mixtures of Ca-bentonite and graphite

\begin{tabular}{|c|c|c|c|c|c|c|}
\hline \multirow[b]{2}{*}{ Mixing Method } & \multirow{2}{*}{$\begin{array}{l}\text { Additive Contents } \\
\text { (wt } \%)\end{array}$} & \multirow{2}{*}{$\begin{array}{c}\text { Dry } \\
\text { Density } \\
\left(\mathrm{g} / \mathrm{cm}^{3}\right)\end{array}$} & \multirow{2}{*}{$\begin{array}{c}\text { Water } \\
\text { Content } \\
\left(w t^{\circ} \%\right)\end{array}$} & \multicolumn{3}{|c|}{ Thermal Conductivity (W/mK) } \\
\hline & & & & Mixture & Pure & Gap \\
\hline \multirow{4}{*}{$\begin{array}{l}\text { Mixer stirring } \\
\text { Mixing }\end{array}$} & 1 & 1.52 & 10.95 & 0.73 & 0.64 & 0.09 \\
\hline & 5 & 1.48 & 10.96 & 0.92 & 0.59 & 0.33 \\
\hline & 7 & 1.45 & 11.53 & 1.00 & 0.57 & 0.43 \\
\hline & 8.5 & 1.45 & 10.98 & 1.07 & 0.55 & 0.52 \\
\hline \multirow{6}{*}{$\begin{array}{l}\text { Roller stirring } \\
\text { Mixing }\end{array}$} & \multirow{2}{*}{1} & 1.61 & 12.81 & 0.9 & 0.82 & 0.08 \\
\hline & & 1.62 & 12.98 & 0.92 & 0.83 & 0.09 \\
\hline & \multirow{2}{*}{2} & 1.59 & 13.72 & 1.02 & 0.80 & 0.22 \\
\hline & & 1.58 & 13.70 & 0.97 & 0.79 & 0.18 \\
\hline & \multirow{2}{*}{3} & 1.58 & 12.98 & 1.07 & 0.79 & 0.28 \\
\hline & & 1.58 & 13.59 & 1.07 & 0.79 & 0.28 \\
\hline
\end{tabular}


Table 5. Thermal conductivity of Ca-Bentonite with the addition of alumina, $\mathrm{CuO}$ and $\mathrm{Fe}_{2} \mathrm{O}_{3}$ additives

\begin{tabular}{|c|c|c|c|c|c|c|c|}
\hline \multirow{2}{*}{\multicolumn{2}{|c|}{ Mixing Method }} & \multirow{2}{*}{$\begin{array}{l}\text { Additive Contents } \\
\qquad(\mathrm{wt} \%)\end{array}$} & \multirow{2}{*}{$\begin{array}{c}\text { Dry } \\
\text { Density } \\
\left(\mathrm{g} / \mathrm{cm}^{3}\right)\end{array}$} & \multirow{2}{*}{$\begin{array}{l}\text { Water } \\
\text { Content } \\
(\mathrm{wt} \%)\end{array}$} & \multicolumn{3}{|c|}{ Thermal Conductivity (W/mK) } \\
\hline & & & & & Mixture & Pure & Gap \\
\hline \multirow{9}{*}{$\begin{array}{c}\text { Mixer stirring } \\
\text { Mixing }\end{array}$} & \multirow{5}{*}{ Alumina } & 1 & 1.52 & 12.26 & 0.73 & 0.65 & 0.08 \\
\hline & & 5 & 1.48 & 12.55 & 0.76 & 0.67 & 0.09 \\
\hline & & 10 & 1.42 & 12.45 & 0.79 & 0.54 & 0.25 \\
\hline & & 15 & 1.33 & 12.36 & 0.82 & 0.43 & 0.39 \\
\hline & & 20 & 1.26 & 12.40 & 0.82 & 0.35 & 0.47 \\
\hline & \multirow{2}{*}{$\mathrm{CuO}$} & 1 & 1.51 & 12.39 & 0.76 & 0.64 & 0.08 \\
\hline & & 10 & 1.42 & 12.65 & 0.67 & 0.60 & 0.07 \\
\hline & \multirow{2}{*}{$\mathrm{Fe}_{2} \mathrm{O}_{3}$} & 1 & 1.53 & 12.53 & 0.73 & 0.73 & 0.00 \\
\hline & & 10 & 1.40 & 12.54 & 0.69 & 0.57 & 0.12 \\
\hline
\end{tabular}

상온에서 보관된 벤토나이트의 함수비는 $12.9 \mathrm{wt} \%$ 정도이 며, 이것을 압축시킨 건조밀도 $1.6 \mathrm{~g} / \mathrm{cm}^{3}$ 의 칼슘 벤토나이 트의 열전도율은 약 $0.77 \mathrm{~W} / \mathrm{mK}$ 정도이었다. 따라서 $1 \mathrm{~W} /$ $\mathrm{mK}$ 을 만들기 위해서는 $0.23 \mathrm{~W} / \mathrm{mK}$ 정도, 약 $30 \%$ 열전도율 이 증가가 필요하였다. CNT의 경우를 보면, Ball Mill을 이 용하여 혼합하였을 때 약 $5.5 \mathrm{wt} \%$ 첨가하면 되는 것으로 나 타났다. Graphite의 경우, 믹서를 통한 Stirring 혼합은 약 $3.55 \mathrm{wt} \%$, Ball Mill을 통한 Stirring 혼합은 약 $2.43 \mathrm{wt} \%$ 첨가 하면 되는 것으로 나타났다. $\mathrm{CuO}$ 의 경우는 실험에 문제가 있는 것으로 판단되기 때문에 결정하기 어렵고, Alumina와 $\mathrm{Fe}_{2} \mathrm{O}_{3}$ 의 경우에는 각각 약 $10.1 \mathrm{wt} \%, 18.9 \mathrm{wt} \%$ 첨가하면 되 는 것으로 나타났다. 전체적으로 열전도율 상승 효과가 가장 큰 것은 Graphite를 혼합한 경우이었으며, 그 다음이 CNT를 혼합한 경우였다.

지금까지 수행된 시험에서 소량의 무기물 첨가로 효과적 으로 경주산 칼슘 벤토나이트의 열전도도를 효과적으로 증 가시킬 수 있음을 실험적으로 확인하였다. 한편, 첨가제 혼 합에 따른 벤토나이트의 기본 성질인 팽윤압과 수리전도도 에 미치는 영향도 평가한다면 국내 고준위폐기물 처분장의 개념 설계에 유용하게 활용될 수 있을 것으로 기대된다.

\section{REFERENCES}

[1] Lee, J.W., Jo, W.J., "Thermal-hydro-mechanical Properties of Reference Bentonite Buffer for a Korean HLW Repository", KAERI/TR-3729/2009, KAERI (2009).

[2] Jun, G.S, Lee, J.W., Jo, W.J., Kang, M.J., Kim, S.S.,
"High-level waste disposal technology development /Engineered barrier development", KAERI/RR-1897 198, KAERI (1999).

[3] Bel, J., Bernier, F., "Temperature criterion related to clay based backfill materials in the framework of a geological repository of heat producing radioactive waste", proc. ICEM'01, The 8th International Conference on Environmental management (2001).

[4] Lee, J.H., Lee, M.S., Choi, H.J., Choi, J. W., "Temperature effect on the swelling pressure of a domestic compacted bentonite buffer", J. of the Korean Radioactive Waste Society, 8(3), pp.207-213 (2010).

[5] Y.M. Tien., C.A. Chu., W.S. Chuang., "The prediction model of thermal conductivity of sand-bentonite based buffer material", France Clays in Natural \& Engineered Barriers for Radioactive Waste Confinement, p.657 (2005).

[6] Beziat, A. Dardaine, M. Mouch, E., "Measurements of the thermal conductivity of clay-sand and clay-graphite mixtures used as engineered barriers for high-level radioactive waste disposal", Applied Clay science, 6 , pp.245-263 (1992).

[7] Michael, J., Gunter, B., "Influence of graphite and quartz addition on the thermo-physical properties of bentonite for sealing heat-generating radioactive waste", Applied Clay Science, 44, pp. 206-210 (2009).

[8] Pacovsky, J., Svoboda, J., Zapletal, L., "Saturation 
Development in the Bentonite Barrrier of the Mock-upCZ Geotechnical Experiment: Physics and Chemistry of the Earth, 32. Elsevier, pp.767-779 (2007).

[9] Vasieek, R., "Mock-up-CZ Experiment, CTU praque, Faculty of Civil Enginering Centre of Experimental Geotechnics". http://ceg.fsv.cvut.cz/EN/ceg-downloads (2007).

[10] Japan Nuclear Cycle Development Institute, H12 Supporting Report2, Repository Design and Engineering Technology, p.431 (2000).

[11] Lee, J.W., Jo, W.J., Jun, G.S., Kang, C.H., "A study on the swelling characteristics of a potential buffer material : effect of ionic strength and temperature on the swelling pressure", KAERI/TR-1318/99, KAERI (1999).

[12] QTM-500, User Guide, Ver. 08, Japan, KYOTO ELECTRONICS,

[13] Coquard, R., Baillis, D., Quenard, D., "Experimental and theoretical study of the hot-wire method applied to low-density thermal insulators", International journal of Heat and Mass Transfer, 49, pp. 4511-4524 (2006).

[14] Yoo, G.M., Lee, S.G., Kim, S.R., "Effect of Multi-wall Carbon nanotube Surface Treatment on the Interface and Termal Conductivity of Carbon Nanotube-based Composites", Journal of Adhesion and Interface, 11(4), pp.174-180 (2010). 